\begin{tabular}{|c|c|c|}
\hline ISSN (Online): 2367-6957 & \multicolumn{2}{|c|}{ ISSN (Print): 2367-6361 } \\
\hline & Izvestiya Journal of Varna University of Economics 1 (2021) & EVVESTIYA \\
\hline & IZVEST IY A & $=$ \\
\hline 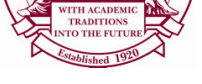 & $\begin{array}{c}\text { Journal of Varna University of Economics } \\
\text { http://journal.ue-varna.bg }\end{array}$ & $\Leftrightarrow$ \\
\hline
\end{tabular}

\title{
TRANSMISSION MECHANISM OF GLOBALIZATION AND ITS IMPACT ON HUMAN WELFARE DEVELOPMENT IN SUB-SAHARAN AFRICAN COUNTRIES
}

\section{Olukayode MAKU ${ }^{1}$, Olorunfemi ALIMI' ${ }^{2}$, Fidelis OGWUMIKE ${ }^{3}$}

\footnotetext{
Department of Economics, Faculty of Social and Management Sciences, Olabisi Onabanjo University, Ago-Iwoye, Ogun State, Nigeria. E-mail: kaymarks73@yahoo.co.uk

2 Department of Economics and Development Studies, Faculty of Management and Social Sciences, Lead City University, Ibadan, Oyo State, Nigeria. E-mail: haleemphemy480@gmail.com

3 Department of Economics, Faculty of Social Sciences, University of Ibadan, Ibadan, Oyo State, Nigeria. E-mail: foogwumike@yahoo.com
}

JEL: E14, F13, F62, I31

\section{Key words:}

globalization, human welfare, basic needs, quality of governance, Sub-Saharan Africa.

\begin{abstract}
The increased intensity of globalization across borders integrated the sub-Saharan African (SSA) countries into the world economy as shown by the increasing degree of trade openness (from $55.4 \%$ in $1980-1984$ to $65.6 \%$ in 2000-2015) and foreign direct investment as a percentage of GDP (from $0.3 \%$ in $1980-1984$ to $2.85 \%$ in 2000 2015). The quality of life of the people in the region improved marginally regarding access to basic needs. However, the effects of globalization on access to basic needs such as water, sanitation, healthcare services have received little attention. Thus, this study investigates the impact of globalization on human welfare in sixteen SSA countries over the period 1980-2015. Using a panel fixed effect approach, the findings revealed that globalization through its various channels (trade openness, capital and financial flows and labour mobility and information technology), improves human welfare indicators in sub-Saharan Africa. However, the low level of good governance in the region deteriorates the development of human wellbeing. Thus, there is a need to improve the quality of governance to enhance the welfare of the people through global interactions.
\end{abstract}

(C) 2021 University of Economics - Varna

Citation: MAKU, O., ALIMI, O., OGWUMIKE, F. (2021). Transmission Mechanism of Globalization and Its Impact on Human Welfare Development in Sub-Saharan African Countries. Izvestiya Journal of Varna University of Economics, 65 (1), pp. 45 - 64.

DOI: 10.36997/IJUEV2021.65.1.45 


\section{Introduction}

All countries in the world have become more linked together through globalization over the last three decades. This cooperation among nations has however turned the players into one big international market. The interaction of various players in the international market has transformed the world into a global village which had proved to be successful in all ramifications. The success story is not limited to economic outlooks but also covers socio-political viewpoints, technological advancement and cultural settings of nations and social groups. The benefits also assisted countries in adopting policy measures and formulating programmes that were aimed towards alleviating poverty and improving the welfare of citizens. However, globalization has brought along with it a large number of economic disorders which have worsened human well-being.

In the Sub-Saharan Africa (SSA) region, the primary goals of the economic reforms since the 1980s have been to reduce structural vulnerability by the integration of trade, capital flows as well as social contacts into the world economy to ensure sustained growth, poverty reduction and human welfare improvements. Regardless of the extended period of economic reforms, in SSA, the majority of her population are still living in abject poverty. The region has not been able to half the total number of poor people in the region as predicted in the Millennium Development Goals (MDGs). From a statistical point of view, the World Bank Development Indicators (2019) revealed that poverty headcount ratio at $\$ 1.90$ per day fell from $58.4 \%$ in 1999 to $50.9 \%, 46.6 \%$ and $42.3 \%$ in 2005,2010 and 2015 respectively. It means that the region only achieved a small reduction in poverty headcount. Likewise, the United Nations Development Programmes (UNDP, 2006) reports that consumption of goods and services in Africa recorded a decline of about 20\% between 1975 and 2005 . The per capita private consumption of SSA grew at a low average rate of about $1.2 \%$ within the periods, 1980-2006 compared to the average values of $1.6 \%$ for Latin America and the Caribbean, 2\% for South Asia and 5.6\% for East Asia and the Pacific (UNDP, 2007; World Bank Report, 2007). With the aim of reducing the number of people in extreme poverty, African countries have introduced different policy reforms ${ }^{1}$ in more fundamental matters such as market deregulation, trade liberalisation and public sector restructuring, including privatisation, but all have not solved human welfare crises.

As a result of this significant discussion, the study makes enquiries on the following questions: What is the effect of trade openness on human welfare changes in SSA countries? What has been the effect of capital and financial flows in SSA 
O. Maku, O. Alimi, F. Ogwumike. Transmission Mechanism of Globalization and Its Impact on Human Welfare Development in Sub-Saharan African Countries

countries on the citizens' well-being? Has each of the labour mobility and information flows impacted significantly on the wellbeing of people in SSA over the past four decades? We seek to understand the causal links between globalization and human welfare development across sixteen sub-Saharan African countries for a period of 1980 to 2015. Unlike the study of Ogwumike, Maku and Alimi (2018), this study extends the frontier of knowledge by examining the effects of major globalization indices (trade openness, capital and financial flows, labour mobility and information flows) on human welfare measures of 16 SSA countries. Furthermore, we decompose human welfare measures into five, which are: access to basic human necessities (i.e. access to basic healthcare services, basic drinking water, and sanitation), mean years of schooling, child mortality, human longevity and human development index respectively and also estimate how they are affected by globalization. The remaining sections are in four parts. The next section provides a brief overview of the literature on the relationship between globalization and human welfare. In the third section, the study presents the estimable model and estimation techniques. The fourth section shows the empirical results and discussions, while the last part concludes with some policy implications.

\section{Brief Review of Literature}

Empirically, many studies exist on the linkage between globalization and various economic development indicators, but only a few focused on the precise linkage between globalization, poverty and welfare changes. We reviewed some empirical literature closely related to our study, ranging from the panel, cross-sectional and time-series data studies. Santarelli and Figni (2002), using narrative techniques and an unrestricted linear regression model, investigated whether globalization reduces or escalates poverty in selected developing countries. They found that financial openness, though not statistically significant, is positively linked to poverty, while trade openness tends not to affect relative poverty. However, financial openness does significantly affect relative poverty. Heshmati (2003) investigated the relationship between income inequality and globalization in selected developing economies. Using a pooled ordinary least square (OLS), the author observes that the low rank of the globalization process is due to political and personal factors which developing countries have limited possibility to affect. He posits that globalization indices explain 7 to $11 \%$ of income inequality among the developing countries. Hammoris and Kai (2004) addressed the precise relationship between globalization, financial deepening and inequality for the entire SSA region between 1980 and 2002 using the unbalanced panel regression technique. The study revealed that globalization reduces 
disparities in income and its impacts depend on the level of development of the country. Also, globalization adversely affects the equalizing effects of financial depth, although it helps reduce inequality in SSA.

Guordon, Maystre and Melo (2008) follow the path of Hammoris and Kai (2004) methodologically and also challenge other earlier empirical studies on developing countries such as Santarelli and Figni (2002) and Heshmati (2003). The authors used the panel regression analysis to establish the link between openness, inequality, and poverty for selected developing countries. The study revealed consistent evidence that the conditional effects of trade liberalisation on income differences correlate with relative factor endowment. Heinrich (2009) evaluates the impact of national symbols and globalization on the wellbeing of 88 selected developing countries. The finding revealed that conventional determinants of production affect national welfare measured by human development index (HDI). The effects of national symbols on HDI are unstable while those of globalization are strong with social globalization having the most substantial impacts.

Niyongabo (2005) investigates the relationship between financial liberalization (measured by private investment) and economic growth for a panel study of 102 countries which also included 30 SSA countries. The findings indicated that financial liberalization has a direct association with real income per capita. Oduh (2012) also reported similar results for Nigeria using the same measures. Using foreign direct investment as a measure of financial openness, Kumar and Pacheco (2012) and Shahbaz (2012) revealed that financial openness improves human welfare in Kenya and Pakistan respectively. The findings were in tandem with the results of Roine, Vlachos, and Waldenstrom (2009) conducted for a study sample of 16 developing countries. Nevertheless, some studies like Obadan and Okojie (2012) and Ahmad (2014) refuted the positive relationship between financial openness and human welfare in SSA countries. For instance, Ahmad (2014) using a generalised method of moments (GMM) approach for a panel study of 21 SSA countries found an adverse effect of financial openness on economic growth. The differences in their empirical findings come from the employed measures of human welfare and estimation techniques.

In a more extensive analysis of human welfare effects of other measures of globalization such as labour mobility and information flows, only very few empirical studies (Khor, 2002; Niyongabo, 2005; Popkin, 2006; Dreher, 2006; Dreher and Gaston, 2006; Dreher et al., 2008; Abbott and Coenen, 2008; Maertens, Colen and Swinnen, 2009; Ogwumike and Maku, 2012; Shahbaz, 2012; Hismmangolu, 2012; and Elgin et al., 2013; Ogwumike, Maku and Alimi, 2018) were found to explore 
O. Maku, O. Alimi, F. Ogwumike. Transmission Mechanism of Globalization and Its Impact on Human Welfare Development in Sub-Saharan African Countries

related dimensions of this globalization component. A sample of 184 cross-country analyses by Dekimpe, Paker, and Sarvary (2000) reveal that the cellular telephone enhanced welfare growth rate. Also, in a survey of 30 SSA countries, Niyongabo (2005) noted that telephone users have a significant and positive effect on human welfare development measured by GDP per capita growth between 1970 and 2000 . Abbott and Coenen (2008) revealed that globalization and advances in information and communication technology (ICT) brings about innovation and opportunities in health care delivery as a measure of human welfare. In a single country study of China, Segal (2008) indicated that science and technology enhance income equality. In another study on the impact of globalization and information technology on language education policy in Turkey, Hismmangolu (2012) contended that ICT flow exerted a positive effect on the English Language development as a measure of educational progress that constitutes a component of human welfare development in Turkey. Similarly, Neculita and Moga (2012) demonstrated that the main driving force for better human welfare development across countries is through technological progress, information, communication, and transport.

In the case of labour flow, the findings of Osabuohien (2007), Maertens et al. (2009), and Shahbaz (2012) revealed that globalization through labour market participation has a positive impact on human welfare. In addition, Gindling and Terrell (2010) examined the nexus among minimum wage, globalization, and poverty in Honduras and reported that high minimum wage rate alleviates poverty. Also, Shahbaz (2012) stated that skilled labour has a significant effect on real GDP per capita growth rate in Pakistan. A plausible explanation for the contradiction in the findings is the small sample size and difference in adopted proxy for labour flow. In recent time, the effectiveness of governance and the rule of law have been found to be significant determinants of welfare. A recent study by Ogwumike, Maku and Alimi (2018) conducted a regional analysis of the links between globalization and human welfare for sixteen SSA countries within the period, 1980-2014. They employed the panel fixed effect approach and found that human welfare development and access to adequate infrastructure are enhanced by trade openness for the four regions. The study discovered that FDI only enhances human welfare in Southern and Eastern African regions. In the Southern part of Africa, the authors found that the high level of social globalization resulted in improved human welfare changes. In the end, the high migration level of workers causes deterioration in welfare development and basic infrastructures in the region. After assessing the relevant studies in the body of existing literature, we discovered that their findings can best be described as inconclusive. Also, it was noticed that existing studies on the links between 
globalization mechanism and human welfare in SSA was conducted on a regional basis (see Ogwumike, Maku and Alimi, 2018). This study deviates from the available literature by establishing the links between globalization transmission mechanisms and human welfare development for SSA countries altogether. This study, therefore, tests the null hypothesis below:

$\mathbf{H}_{\mathbf{0}}$ : Globalization transmission mechanism has no significant impact on human welfare development in SSA countries.

\section{Methodology}

\subsection{Analytical Framework and Model Specification}

This study adapts the exogenous growth theory which states that external variables are responsible for changes in output growth in an economy. The underlying assumption is that economic prosperity is mainly determined by independent and external factors contrary to interdependent or internal factors. These external factors are savings rate, diminishing capital return and technological progress. This study, therefore, hinges on the Solow's (1956) exogenous growth model for building the empirical model of the relationship between globalization and human welfare changes in SSA countries. We utilize the Solow growth model for three reasons: (a) it is easy to modify and estimate compared to other endogenous growth models (Bernanke and Gürkaynak, 2002; Greiner, Regal, and Jin, 2004); (b) the model is also famous as any other endogenous model as there is no compelling evidence that they performed better than the Solow model (Parente, 2001; Solow, 2000); and (c) other types of growth models also employed its framework as it possesses the features of a balanced growth path (Bernanke and Gürkaynak, 2002). The model adopted for this study emanates from the theoretical model of Maku (2015) (which) stated:

$$
\ell^{H D I}=A_{0} K^{\beta} \ell^{\eta \ln q+\delta n t}
$$

Where: $\ell$ is exponential, $H D I$ is human development index, $A$ is technological progress or multi-factor, $K$ is physical capital, $q$ is the vector of transmission mechanisms of globalization, and $\beta, \eta, \delta, n, t$ are parameters.

The above equation represents the theoretical model for this study to investigate the effect of globalization on human welfare changes. Equation (1) shows that $q$, that is, a vector of transmission mechanism sub-channels which is exogenously determined. The study then incorporates globalization measured by trade openness (TRD), capital flow measured by portfolio investment (PFI) and foreign direct 
O. Maku, O. Alimi, F. Ogwumike. Transmission Mechanism of Globalization and Its Impact on Human Welfare Development in Sub-Saharan African Countries

investment (FDI), technology measured by information and communication technology (ICT) and labour mobility measured by migration of labour (LBM). Previous studies have also considered governance as one of the components of vector $q$ that influence human welfare. For instance, Prasad et al. (2004) and Harrisson (2006) recognized good governance index (GGI) as an essential factor that explains the capital flow-growth-human welfare nexus. Incorporating all these factors into equation (1), it becomes:

$$
\ell^{H D I}=A_{0} K^{\beta} \ell^{\sum \eta \ln (T R D, P F I, F D I, L B M, I C T, G G I)+\delta n t}
$$

The value of $n$ is used to measure population growth rate of social welfare which is presumed to be equal to the exogenous growth rate of labour, whereas $t=1$. More so, $K$ is capital-output ratio measured as the percentage share of gross fixed capital formation to gross domestic product $(F C F)$. The equation becomes:

$$
\ell^{H D I}=A_{0} F C F^{\beta} \ell^{\sum \ln (T R D, P F I, F D I, L B M, I C T, G G I)+\delta n}
$$

The above mathematical equation revealed the exponential growth model used for analysing the impact of globalization on human welfare changes in SSA. Taking the logarithm of both sides of the equation, the model is specified in a linear panel form to capture both country and time effect.

$$
\begin{aligned}
H D I_{i t}= & a_{0}+\beta \ln F C F_{i t}+\eta_{1} \ln T R D_{i t}+\eta_{2} \ln P F I_{i t}+\eta_{3} \ln F D I_{i t}+\eta_{4} \ln L B M_{i t} \\
& \eta_{5} \ln I C T_{i t}+\eta_{6} \ln G G I_{i t}+\delta n_{i t}+u_{1 t}
\end{aligned}
$$

Where: $a_{0}=\ln A_{0}, \beta, \eta_{1-6}$ are parameters; and human welfare index and indices of access to basic needs indices were regressed on the essential components of globalization. The welfare index variables were life expectancy at birth (LEI), infant mortality rate (IMR) and mean years of schooling of adults (MYS). The indices of access to basic needs were improved water (\% of the population with access) (WAT), improved sanitation facilities (\% of the population with access) (SAN) and health care services ( $\%$ of the population with access) (HCS).

\subsection{Estimation Techniques}

The study adopted the fixed effects estimation technique to estimate the relationship between the variables specified in our panel model (4). The choice of this 
estimation technique resulted from its assumption that the unobserved effects vary between countries (i.e., heterogeneous) rather than a random term as assumed using the random effects technique. The cross section weights (a feasible GLS specification considering the presence of cross-section heteroskedasticity) was taken to correct for cross-section heteroskedasticity and autocorrelation of idiosyncratic disturbance. It ensures that the fixed estimator is efficient and consistent for analysing this study as used by earlier empirical studies like Hammoris and Kai (2004), Guordon et al. (2008), Heinrich (2009), among others. To precisely ensure the efficiency of the fixed effects estimator, the Hausman test is estimated to determine the best efficient estimator between fixed and random effects.

Table 1

\section{Descriptive Statistics for SSA Pooled Data}

\begin{tabular}{lrrrrrr}
\hline & Mean & Max & Min & $\begin{array}{c}\text { Std. } \\
\text { Dev. }\end{array}$ & Obs. & $\begin{array}{c}\text { Cross } \\
\text { Sections }\end{array}$ \\
\hline Human Development Index & 40.38 & 73.70 & 16.35 & 13.48 & 560 & 16 \\
(HDI) & 53.05 & 74.52 & 26.76 & 7.65 & 560 & 16 \\
Life Expectancy Index (LEI) & 82.52 & 169.60 & 12.80 & 34.69 & 560 & 16 \\
Infant Mortality Rate (IMR) & 3.09 & 8.90 & 0.50 & 2.04 & 560 & 16 \\
Mean Year of Schooling (MYS) & 31.67 & 92.14 & 3.16 & 22.53 & 560 & 16 \\
Access to Sanitation (SAN) & 61.15 & 99.80 & 25.22 & 19.44 & 560 & 16 \\
Access to Water (WAT) & 49.94 & 84.40 & 18.22 & 11.81 & 560 & 16 \\
Health Care Service (HCS) & 61.09 & 137.11 & 6.32 & 26.88 & 560 & 16 \\
Trade Openness (TRD) & 53.63 & 71.45 & 47.00 & 4.89 & 560 & 16 \\
Share of Working Age & 1.81 & 20.12 & -8.59 & 2.78 & 560 & 16 \\
Population (POP) & -0.10 & 101.07 & 102.38 & 7.29 & 560 & 16 \\
Foreign Direct Investment (FDI) & & & & \\
Portfolio Investment (PFI) & 17.62 & 46.10 & -0.06 & 8.27 & 560 & 16 \\
Fixed Capital Formation (FCF) & 23.25 & 298.42 & 0.63 & 50.10 & 560 & 16 \\
Access to Telephone (ICT) & -0.03 & 52.21 & -46.54 & 6.28 & 560 & 16 \\
Labour Migration (LBM) & 2.75 & 6.65 & 1.67 & 5.71 & 560 & 16 \\
Good Governance Index (GGI) & & & & & &
\end{tabular}

Source: Authors' computation (2020). 
O. Maku, O. Alimi, F. Ogwumike. Transmission Mechanism of Globalization and Its Impact on Human Welfare Development in Sub-Saharan African Countries

\subsection{Data Description}

The countries comprise of four nations from the four SSA regions, which are Gabon, Central African Republic, Cameroon, Rwanda, Kenya, Tanzania, Mauritius, Tanzania, South Africa, Malawi, Botswana, Mozambique, Nigeria, Ghana, Benin, and Niger. The data are within 1980-2015. The data was sourced from the World Development Indicators (2018), except for the good governance index (GGI), obtained from the International Country Risk Guide (ICRG, 2018) ${ }^{2}$.

The descriptive characteristics of our variables are presented in Table 1. The mean value of human development index (HDI), life expectancy index (LEI), infant mortality rate (IMR, per 1,000 live births), and mean year of adult schooling (MYS) stood at $40.4 \%, 53.1 \%, 82.5 \%$ and 3.09 years, respectively. These values reflect the low human welfare status of SSA countries. Also, the average amount of the percentage of people with access to improved sanitation (SAN), water (WAT) and health care services (HCS) respectively stood at $31.7 \%, 61.2 \%$, and $49.9 \%$. The estimates reveal that the majority of people in SSA countries lack adequate access to necessities of life. The mean value of trade flows (TRD) as a share of GDP is $61.1 \%$. It implies that SSA countries are relatively globalized regarding trade flow. Also, the mean value of working population (POP, as a proportion of total population size) stood at $53.6 \%$, indicating that active working age population size dominates SSA countries.

The mean values of foreign direct investment (FDI) and portfolio investment (PFI) as the share of gross domestic product (GDP) are $1.81 \%$ and $-0.10 \%$, respectively. It reveals that SSA countries are relatively less globalised regarding capital flows. Also, the mean value of gross fixed capital formation (FCF) as a share of GDP and proxy of domestic capital formation stood at $17.6 \%$. These indicate that SSA countries have fairly mobilised domestic capital for investment. The mean values of labour mobility (LBM, proxied by net labour migration as a share of the working-age population), and information and technology penetration rate (ICT, proxied by telephone line density per 1000 people) are $-0.03 \%$ and $23.25 \%$ respectively. The mean value of labour mobility indicates the loss of quality in the productive workforce in the SSA region as the level of emigrant-to-total active population as net value (as a share of working age group) is higher than the percentage of immigrants. The average of ICT penetration rate suggests that SSA countries are less socially globalised via telephone connectivity as a means of information flow within the reviewed periods. Also, the mean value of governance performance rate (GGI) stood at 2.75, implying that SSA countries have weak governance settings and an ineffective governance system. 


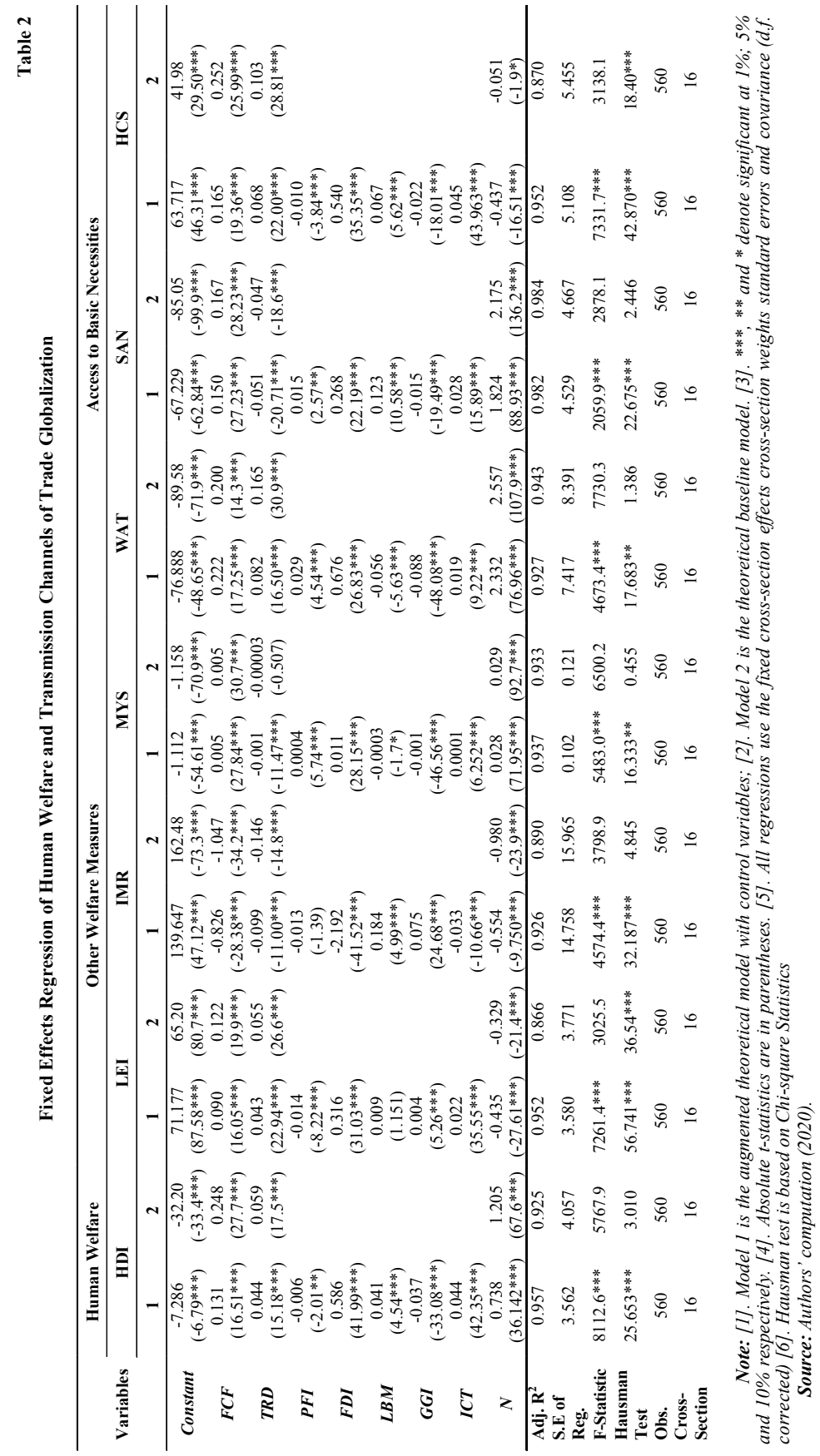


O. Maku, O. Alimi, F. Ogwumike. Transmission Mechanism of Globalization and Its Impact on Human Welfare Development in Sub-Saharan African Countries

\section{Discussion of Empirical Findings}

In Table 2, we presented the estimation results of the relationship between transmission mechanisms of globalization and human welfare using the panel fixed effects approach. The Hausman test results confirmed the appropriateness of the estimation approach as they were found statistically significant at $5 \%$. The discussion of findings of the links between human welfare and globalization mechanisms are explained in the sub-sections.

\subsection{Human Welfare and Trade Openness Nexus in Sub-Saharan Africa}

Table 2 shows that trade openness was found to be positive and significant to critical dimensions of human welfare (such as human development index, life expectancy index, access to improved water, and healthcare services) in sub-Saharan Africa countries. However, the intensity of the effect is relatively low compared to the expected, regarding magnitude. This finding is consistent with the apriori expectation as globalization via trade-oriented growth channel is expected to be human welfare enhancing concerning reduction in income inequality and poverty. It is supposed to improve life expectancy, reduce infant mortality rate, and improve access to people's necessities of life. In magnitude terms, HDI, LEI, reduction in the IMR, lower MYS, access to improved WAT, lesser SAN, and HCS improved by $0.44 \%, 0.43 \%,-0.99 \%$, $-0.01 \%, 0.82 \%,-0.51 \%$, and $0.68 \%$ respectively due to $10 \%$ changes in trade flows.

The result is in line with the practical conclusions of Dollar and Kraay (2004), Lee and Vivarelli (2006) and Harrison (2006) that trade fosters economic growth, enhances poverty alleviation and welfare development. More so, it agrees with the findings of Obadan and Okojie (2012), Oduh (2012) suggesting that globalization through trade relations is an effective means of generating employment, enhancing human welfare, reducing poverty, and income inequality. This also supports a country level study in Pakistan by Shahbaz (2012) using real GDP per capita as a measure of welfare changes.

Furthermore, studies like Guordon et al. (2008) and Afaha and Njogo (2012), etc. reported contrary findings to our results. They argued that trade flow as a channel of globalization does not enhance human welfare. Also, in a single equation analysis, Heshmati (2003) finds that the trade globalization index explains 7 to $11 \%$ human welfare deterioration among developing countries. However, this study establishes that in a much higher magnitude using the same disaggregated approach, TRD explains $93 \%$ of changes in human welfare development and lack of access to infrastructure facilities like HCS in the SSA region. In a SSA specific study, Adeyemi 
et al. (2006) pooled multiple regression analysis reported that international trade had impacted negatively on human development in the SSA region. The conclusion of Bardhan (2005), Blouin, Chopra and Van der Hoeven (2009), Neculita and Neculita (2012) explains the trade-enhancing effect on human welfare development in SSA countries. Neculita and Moga (2012) conclude that the main driving force for better economic prosperity in trade flows across countries is through technological progress, information, communication and transport, and institutional progress.

\subsection{Human Welfare and Transmission Channel of Capital and Financial Globalization in Sub-Saharan Africa (SSA)}

This section reports the observed results of the combined effect of capital and financial flows as a channel of globalization on human wellbeing in SSA, also presented in Table 2. From the aggregated model, the result revealed that domestic capital and foreign capital dimension of globalization have direct effects on the HDI, LEI, MYS, access to improved WAT, SAN, and HCS, while it exerts adverse impact on IMR within the periods. Specifically, HDI, LEI, reduction in the IMR, MYS, access to improved WAT, SAN, and HCS improved by $1.31 \%, 0.9 \%,-8.26 \%, 0.05 \%$, $2.22 \%, 1.50 \%$, and $1.65 \%$ respectively due to $10 \%$ changes in domestic capital. Likewise, the findings showed that a $10 \%$ change in FDI enhanced HDI, LEI, reduction in IMR, MYS, access to improved WAT, SAN, and HCS by $5.86 \%, 3.16 \%$, $-21.92 \%, 0.11 \%, 6.76 \%, 2.68 \%$, and $5.40 \%$ correspondingly. The portfolio investment suggested negative effects on the HDI, LEI, IMR, and access to improved HCS in the SSA. They do not conform with theoretical expectation regarding signs except IMR. Conversely, they were significant statistically at 0.01 critical level. It showed that a $10 \%$ increase in PFI deteriorates HDI, LEI, IMR, and access to improved HCS by $-0.06 \%,-0.14 \%,-0.13 \%$, and $-0.10 \%$ respectively. However, PFI reported a positive and significant impact on MYS, improved access to clean water, and sanitation in SSA within the periods considered. Thus, a $10 \%$ increase in PFI improved MYS, improved access to clean WAT, and SAN by $0.004 \%, 0.29 \%$, and $0.15 \%$ correspondingly.

The comparative analysis indicated that domestic and foreign capital flows enhance human welfare development and access to improved basic need, while the financial tide of globalization mostly worsens critical human welfare indicators (HDI, LEI, and HCS). Summarily, it suggests that unlike PFI as a financial channel of globalization, FDI a capital dimension of openness is a significant determinant of human welfare development in the SSA region. The finding supports the empirical results of scholars like Shahbaz (2012) and Kumar and Pacheco (2012), Santarelli and 
O. Maku, O. Alimi, F. Ogwumike. Transmission Mechanism of Globalization and Its Impact on Human Welfare Development in Sub-Saharan African Countries

Figni (2002) that openness to foreign investment enhanced the development of human welfare in some selected developing countries. Hammoris and Kai (2004) noted that financial flow does improve not only the wellness of citizen in SSA countries but also has an equalising effect on income distribution. However, the result negates the findings of Obadan and Okojie (2012) and Ahmad (2014) that financial globalization hurts human welfare development. This difference in findings emanates from the measures of human welfare employed by these studies.

\subsection{Human Welfare and Transmission Channel of Labour Mobility and Information Flow in Sub-Saharan Africa (SSA)}

The results of the augmented models show that at $1 \%$ critical level, governance as an institutional control variable exerted a positive and significant effect on LEI and IMR, while it has an inverse and significant association with HDI, MYS, access to improved WAT, SAN, and HCS in the SSA sub-region. These effects were not in line with the theoretical expectations except for LEI. The reported estimates indicate that a $10 \%$ increase in the quality of GGI (increase in governance ineffectiveness) deteriorates HDI, MYS, WAT, SAN, and HCS by $-0.37 \%,-0.01 \%,-0.88 \%,-0.15 \%$, and $-0.22 \%$ respectively and improves LEI and IMR by $0.041 \%$ and $0.75 \%$ respectively. It reflects that improvement in governance is weak in SSA countries which have a deteriorating effect on human welfare, other welfare measures and access to basic needs. The result is similar to the findings of previous studies such as Dreher and Gaston (2006), Dreher, Gaston, and Martens (2008), Ogwumike and Maku (2012), among others. Our findings suggest that the low level of good governance is one of the most significant factors regarding statistical properties and magnitude that lowered human welfare development, life expectancy index, IMR and limits the access of people to basic needs of life in the SSA region.

Furthermore, labour immigration and emigration (Net LBM) was found to have a positive impact on HDI, LEI, IMR, access to improved SAN and HCS in the region. However, it exerted an inverse relationship with MYS, and access to improved WAT in SSA. The reported effects were in tandem with theoretically expected signs except for the nexus between MYS and access to improved water. In magnitude terms, a 10\% increase in net LBM enhanced HDI, IMR, SAN, HCS and reduced IMR, MYS and WAT respectively by $0.41 \%, 1.84 \%, 1.23 \%, 0.67 \%$, and $1.84 \%, 0.003 \%$ and $0.56 \%$ respectively. From the high prevalence of labour emigrants over immigrants, labour mobility was found to exert an adverse effect on human welfare changes in SSA region.

The effect of information flow measured by access to the telephone network on human welfare, other welfare measures, and access to necessities in SSA was 
discussed based on the estimates reported on the table. Access to a telephone as a channel of information dimension of globalization exert a positive and significant association with HDI, LEI, improved access to SAN, and HCS, while it had an indirect impact on IMR in the region. It was found statistically significant at $1 \%$. These effects conform to the apriori expectations. The result indicates that a $10 \%$ increase in telephone access enhanced HDI, LEI, SAN, HCS, and reduction in IMR respectively by $0.44 \%, 0.22 \%, 0.28 \%, 0.45 \%$, and $-0.33 \%$ correspondingly. The observed outcomes of this study conform to the theoretical expectations. The Information flow via access to a telephone network has been a significant factor that enhances human welfare development, reduces the incidence of IMR and improves peoples' access to basic needs of life. This outcome complements the argument of Khor (2002) that technical changes are a significant determinant of human welfare in a highly populated and poor developing country like Bangladesh that SSA countries shared similar characteristics. Also, information flow was found to enhance human well-being significantly in the SSA region for all of its proxies such as HDI, LEI, IMR, MYS, and access to essential amenities like WAT, SAN, and HCS. Empirical studies (Dreher, 2006; Dreher and Gaston, 2006; Dreher, Ogwumike and Maku, 2012) show that information flow as a component of KOF social globalization index enhances growth and human well-being in developing countries.

\section{Conclusion and Policy Implication}

This study investigates the impact of globalization through its various channels such as trade openness, capital and financial flows and labour mobility and information technology on human welfare in sixteen SSA countries within the period of 1980-2015. The study used the panel fixed effects method to investigate the links. This study considered extensive measures of welfare (human development index, life expectancy index, infant mortality rate, mean year of schooling, and access to basic needs of life such as water, sanitation, and healthcare services) as distinct from earlier empirical studies. Empirical evidence indicated that trade openness enhanced human welfare development and the access of people to infrastructural facilities in the SSA regions as a result of adopted and instituted differential trade reforms over the years. Findings further revealed that capital flow through foreign direct investment has a positive impact on welfare mainly concerning human development, life expectancy combating infant mortality rate, and enhanced access to sanitation and human care services in the SSA region. Portfolio investment was found to deteriorate human welfare development in the SSA region. 
Furthermore, the results reveal that information flow via the number of telephone line subscribers exerted a positive impact on human welfare development, infant mortality rate, and improved access to water in the region. Furthermore, high labour migration and emigration of experts was found to worsen human welfare development and hinder essential infrastructural growth in SSA. Also, inadequate and ineffective governance has been established to have the highest negative impact on human wellbeing improvement in the region. Consequently, there is a need for policymakers in each SSA country to continuously increase the adoption and utilisation of comprehensive growth-oriented trade policy tools such as reduced tariffs and non-tariff barriers to guide trade interactions with the global world, primarily via exports promotion strategy to facilitate development in human well-being. More so, governance as a crucial determinant of human welfare development in the region requires guided and transparent operations in its implementation of policies that directly affect the people, eradicate corruption, foster political stability and further enhance the adherence to the rule of law.

\section{End Notes}

${ }^{1}$ Policy programmes like Structural Adjustment Programmes (SAPs), Poverty Reduction Strategies (PRSs), Millennium Development Goals (MDGs), Social Protection and Pro-poor growth strategies.

${ }^{2}$ https://dataverse.harvard.edu/dataset.xhtml?persistentId=doi:10.7910/DV4YHTPU

\section{References}

1. Abbott, P. A. \& Coenen, A. (2008). Globalisation and advances in information and communication technologies: the impact on nursing and health. Nursing Outlook, 56(5), 238-246.

2. Adeyemi, S. L., Ijaiya, G. T., Ijaiya, M. A. \& Kolawole, S. D. (2006). Determinants of human development in Sub-Sahara Africa. Africa Journal of Economic Policy, 13(2), pp. 21-35.

3. Afaha, J. S. \& Njogo, B. O. (2012). Trade openness and its effect on the Nigerian economy (1970-2010). Arabian Journal of Business and Management Review (OMAN Chapter), 2(1), pp. 50-73.

4. Ahmad, F. (2014). Turkey: the quest for identity. Oneworld Publications, London, England.

5. Atoyebi, O. K., Adekunjo, F. O., Edun, O. \& Kadiri, K. I. (2012). Foreign Trade and Economic Growth in Nigeria an Empirical Analysis. Journal of Humanities and Social Science, 2(1), pp. 73-80. 
6. Bardhan, P. (2005). Institutes matter, but which ones? Economics of Transition, 13(3), pp. 499-532.

7. Beine, M., Lodigiani, E. \& Vermeulen, R. (2012). Remittances and financial openness. Regional Science and Urban Economics, 42(5), pp. 844-857.

8. Bernanke, B. S. \& Gurkaynak, R. S. (2002). Is growth exogenous? Taking Mankiw, Romer and Weil seriously. In: NBER Macroeconomics Annual 2001 MIT Press, 16, 11-72.

9. Bhagwati, J. \& Srinivasan, T. N. (2002). Trade and poverty in the poor countries American Economic Review, 92, 180-183.

10.Blouin, C., Chopra, M. \& Van der Hoeven, R. (2009). Trade and social determinants of health. The Lancet, 373/9662, 502-507.

11.Chen, S. \& Ravallion, M. (2004). How have the world's poorest fared since the early 1980s? World Bank Research Observer, 19(2), 141-169.

12. Clupper, R. (2002). Approaches to Globalisation and inequality within the international system. Paper prepared for UNRISD project on Improving Knowledge on Social Development in International Organisation, September.

13. Dekimpe, M., Parker, P. \& Sarvary, M. (2000). Globalization: Modelling technology adoption timing across countries. Technological Forecasting and Social Change 63, pp. 25-42.

14. Dollar, D \& Kraay, A. (2004). Trade, growth, and poverty. Economic Journal, 114, pp. 22-49.

15. Dreher, A. \& Gaston N. (2006). Has globalisation increased inequality? KOF Swiss Institute for Business Research, Working Papers No. 140, June 2006.

16. Dreher, A. Gaston, N. \& Martens, P. (2008). Measuring globalisation: Gauging its consequence. New York, Springer.

17. Dreher, A. (2006). Does globalisation affect growth? Empirical evidence from a new Index. Applied Economics, 38(1), pp. 1091-1110.

18. Elgin, C., Goksel, T., Gurdal, M. \& Orman, C. (2013). Religion, income inequality, and the size of the government. Economic Modelling, 30(C), pp. 225-234.

19. Faber, B. \& Gerritse, L. (2012). Trade integration, market size, and industrialisation: evidence from China's National Trunk Highway System. Review of Economic Studies, 81(3), pp. 1046-1070.

20. Fosu, A. K. \& Mold, A. (2008). Gains from trade: implication for labour market adjustment and poverty reduction in Africa. African Development Review/Reme Africaine de Development, 20(1), pp. 20-48.

21. Gindling, T. H. \& Terrell, K. (2010). Minimum wages, globalization, and poverty in Honduras. World Development, 38(6), pp. 908-918. 
O. Maku, O. Alimi, F. Ogwumike. Transmission Mechanism of Globalization and Its Impact on Human Welfare Development in Sub-Saharan African Countries

22. Gold, K. (2009). Globalisation and poverty: Comparative analysis of Bangladesh and Nigeria. ASBBS annual conferences: Las Vegas, February.

23. Greiner, M., Regal, C. A. \& Jin, D. S. (2004). Observation of resonance condensation of fermionic atom pairs. Physical Review Letters, 92(4), 040403.

24. Guordon, J. Maystre, N. \& Melo, J. (2008). Openness, inequality, and poverty: Endowment matter. Journal of International Trade and Economic Development, 17(3), 343-378.

25. Hai, S. Minhaj A. R. \& Mujahid Y. (2006). Impact of globalisation, liberalization on growth, poverty, and income inequality: A case of Pakistan. Retrieved from https://editorialexpress.com/cgi-bin/conference/download.cgi?db_ name $=$ SERC2007 \&paper_id $=241$

26. Hammoris, S. \& Kai H. (2004). Globalisation, financial depth, and inequality in Sub-Saharan Africa. Working Paper Series 67, Department of Economics, University of Ethiopia.

27. Harrison, A. (2006). Globalisation and poverty. NBER Working Paper No. 12347. Retrieved from http://www.nber.org/papers/w12347

28. Heinrich, A. (2009). National symbol, globalisation and the well-being of nations. MPRA Paper No 14882. Available online at http://mpra.ub.unimuenchen.de/14882/

29. Heshmati, A. (2003). The relationship between income inequality and globalisation. MPRA Paper No. 3897

30. Hismmangolu, M. (2012). The impact of globalisation and information technology on language education policy in Turkey. Procedia-Social and Behavioural Sciences 31, pp. 629-633.

31. Jalil, A. (2012). Modelling income inequality and openness in the framework of Kuznets curve: new evidence from China. Economic Modelling, 29(2), pp. 309-315.

32. Khor, M. (2002). A perspective of globalisation and its implications for developing countries. Paper presented at the CSGR conference on "Globalisation Growth (In) Equality", University of Warwick. Retrieved from http://www. warwick.ac.uk/fac/soc/CSGR/ pkhor.pdf

33. Kumar, S. \& Pacheco, G. (2012). What determines the long run growth rate in Kenya? Journal of Policy Modeling, 34(5), pp. 705-718.

34. Lee, E. \& Vivarelli, M. (2006). The social impact of globalisation in the developing countries. Discussion paper No 1925.

35. Maertens, M. Colen, L. \& Swinnen F. M. (2009). Globalisation and poverty in Senegal: A worst-case scenario? UNDP Working Paper Series. 
36. Maku, O. E. (2015). Globalisation and human welfare in Sub-Saharan Africa (1980-2012) (Unpublished PhD Thesis), University of Ibadan, Nigeria.

37. Milanovic, B. \& Squire, L. (2005). Does tariff liberalisation increase wage inequality? Some empirical evidence. World Bank Policy Research Working Paper No 3571, World Bank Washington, DC.

38. Neculita, M. \& Moga, L. M. (2012). The regionalisation, commercial policies and the trade liberalization impact on national economy. Procedia Economics and Finance, 3, pp. 1049-1054.

39. Neculita, M. \& Neculita, V. (2012). Romania's competitiveness and competitive position in global context. Economics and Applied Informatics, (2), pp. 115-122.

40. Neutel. M. \& Heshmati, A. (2006). Globalisation inequality and poverty relationship: a cross-country evidence. Discussion Paper No 2223.

41. Niyongabo, J. (2005). Where sustainable agriculture means agricultural productivity? The case study of Gikongoro in Southwestern Rwanda. Unpublished Master's Thesis, Department of Economic History, Lund University, Lund.

42. Obadan, M. \& Okojie, E. I. (2012). An empirical analysis of the impact of trade on economic growth. Jos Journal of Economics, 4(1), 1-23.

43. Oduh, M. (2012). Trade openness and output variability in Nigeria: implication for EU-ACP Economic Partnership agreement Developing Country Studies 2(7), pp. 73-84.

44. Ogwumike, F. O. \& Maku, O. (2012). Globalisation and economic growth in Nigeria: a multi-dimensional analysis. Pakistan Journal of Social Sciences, 9(2), pp. 89-95.

45. Ogwumike, F. O., Maku, O. E. \& Alimi, O. Y. (2018). Human welfare and transmission channel of globailization: Empirical evidence from Sub-Saharan African regions. Pertanika Journal of Social Sciences and Humanities, 26(3), 1729-1756.

46. Osabuohie, E. S. (2007). Trade openness and economic performances of ECOWAS members - Reflection from Ghana and Nigeria. Available on http://eprintscovennatuniversity. edu.ng/3961/Trade_and_Openness_IN_ECOWAS.pdf.

47. Parante, S. (2001). The failure of endogenous growth, knowledge. Technology and Policy, 13(1), pp. 49-58.

48. Popkin, B. M. (2006). Technology, transport, globalisation and the nutrition transition food policy. Food Policy, 31(6), pp. 554-569.

49. Prasad, S. Kenneth R. Shang-Jin, W. \& Kose, M. A. (2004). Effects of financial globalisation on developing countries: some empirical evidence. In Harrison A. (2006) Globalisation and poverty. NBER Working Paper No. 12347. Available on http://www.nber.org/papers/w12347 
O. Maku, O. Alimi, F. Ogwumike. Transmission Mechanism of Globalization and Its Impact on Human Welfare Development in Sub-Saharan African Countries

50. Ravallion, M. (2006). Looking beyond averages in trade and poverty debate. World Development, 34(8), pp. 1374-92.

51. Roine, J., Vlachos, J. \& Waldenstrom, D. (2009). The long-run determinants of inequality: what can we learn from top income data? Journal of Public Economics, 93(7), pp. 974-988.

52. Santarelli, E. \& Figni P. (2002). The accelerating effect of globalisation on poverty: Evidence from developing countries. DFID Project Paper.

53. Segal, A. (2008). Autonomy, security, and inequality: China, India, the United States, and the globalization of science and technology. Technology in Society, 30(3), pp. 423-428.

54. Shahbaz, M. (2012). Does trade openness affect long-run growth? Cointegration, causality and forecast error variance decomposition tests for Pakistan. Economic Modelling, 29(6), pp. 2325-2339.

55. Solow, R. M. (1956). A contribution to the theory of economic growth. The Quarterly Journal of Economics, 70(1), pp. 65-94.

56. Solow, R. M. (2000). Growth theory: an exposition. OUP Catalogue.

57. United Nations Development Programme (UNDP, 2006). Human Development Report. New York: Oxford University Press.

58. United Nations Development Programme (UNDP, 2007). Human Development Report. New York: Oxford University Press.

59. United Nations Development Programme (UNDP, 2008). Human Development Report. New York: Oxford University Press.

60. United Nations Development Programme (UNDP, 2012). Assessing Progress in Africa towards the Millennium Development Goals: MDG Report.

61. United Nations Development Programme (UNDP, 2013). Human Development Report. New York: Oxford University Press.

62. United Nation Commodity Trade Database (UNCTAD, 2005). World Investment Report 2005, Trend and Determinants. New York, USA.

63. United Nation Commodity Trade Database (UNCTAD, 2006). World Investment Report 2006, Trend and Determinants New York, USA.

64. United Nation Commodity Trade Database (UNCTAD, 2013). World Investment Report.

65. Wagle, U. R. (2007). Are economic liberalisation and equality compatible? Evidence from South Asia. World Development, 35(11), pp. 1836-1857.

66. World Bank (2007). World Development Report, 2007. Washington DC, The World Bank. 
67. World Bank (2018). World Development Indicators. Washington DC, The World Bank.

68. World Bank (2019). World Development Indicators. Washington DC, The World Bank. 